\title{
Feeding in neonates with antenatal doppler abnormalities- a systematic review and meta-analysis
}

Rajendra Prasad Anne ( $\square$ rajendra.omc@gmail.com )

All India Institute of Medical Sciences- Bibinagar https://orcid.org/0000-0002-1572-4453

Abhishek S Aradhya

Ovum hospitals, Hoskote

Srinivas Murki

Paramitha Childrens Hospital, Hyderabad

\section{Research Article}

Keywords: Early feeding, rapid advancement, necrotizing enterocolitis, feeding intolerance, mortality

Posted Date: December 21st, 2021

DOI: https://doi.org/10.21203/rs.3.rs-1163424/v1

License: () (i) This work is licensed under a Creative Commons Attribution 4.0 International License. Read Full License 


\section{Abstract}

Preterm neonates with antenatal doppler abnormalities are at increased risk of necrotizing enterocolitis (NEC). In these neonates, we did a meta-analysis to compare the impact of early versus late initiation of feeding, and slow versus rapid feed advancement on the important neonatal outcomes. The databases of PubMed, Embase, Cochrane central, CINAHL and google scholar were searched on $6^{\text {th }}$ September 2020. We included all randomized controlled trials addressing the study objective(s). The risk of bias was assessed using the Risk of Bias tool, version 2. Certainty of evidence was assessed using the GRADE (Grading of Recommendations Assessment, Development and Evaluation) approach. Early feeding did not increase the incidence of NEC stage 2 or more (odds ratio/OR 1.27, 95\% confidence interval/Cl 0.83, 1.96; 6 studies, 772 participants) and mortality (OR 0.79, 95\% Cl 0.4, 1.57; 3 studies, 498 participants). A trend was noted towards an increased incidence of feeding intolerance (OR 1.37, 95\% $\mathrm{Cl} 0.98,1.92)$. There was a significant reduction in time to reach full feeds, duration of total parental nutrition, duration of hospital stay, and rates of hospital-acquired infections. The time to regain birth weight was not different. Rapid feed advancement decreased the time to reach full feeds, without affecting other outcomes. The overall certainty of the evidence was rated low. Heterogeneity was not significant. Conclusion: There is low-certainty evidence to recommend early feed initiation in preterm neonates with antenatal doppler abnormalities. The data is insufficient to make a recommendation on the rapidity of feed advancement.

\section{Introduction}

Preterm infants are at increased risk of various adverse outcomes compared to the term population in terms of feed intolerance, necrotizing enterocolitis, infections, respiratory morbidities- bronchopulmonary dysplasia, growth failure in short term and abnormal neurodevelopment in the long term. Neonates with abnormal antenatal Doppler of umbilical artery in the form of absent or reverse end diastolic flow (AREDF), or increased resistance to blood flow in ductus venosus and inferior vena cava, or middle cerebral artery redistribution are a subset of preterms with even further increased risk of morbidities [1]. These neonates are usually delivered preterm and are small for gestation (SGA). In the fetal life, they are exposed to chronic hypoxia leading to preferential shunting of blood to the brain at the expense of circulation to the gut. Postnatally, SGA babies have reduced wall thickness, length, villous weight, and crypt depth [2]. Furthermore, this subset of neonates also has intestinal dysbiosis and an alteration of the proliferation-apoptosis homeostasis of the gut. Hence there are structural, functional, and secretory changes in these neonates and enteral feeding in already compromised gut exacerbates feed intolerance and maybe one of the associated etiologies for the development of NEC and thereby poor outcomes [3].

A systematic review of 14 observational studies has shown an increased risk of NEC in neonates with antenatal doppler abnormalities with odds of 2.13 (95\% $\mathrm{Cl}$ 1.4-3.0) compared to controls without AREDF [4]. In preterms to prevent NEC, several strategies like using mother's own milk (MOM), donor milk, standardized feeding regimen, probiotics avoiding prolonged empirical antibiotics, avoiding proton pump inhibitors are being used [5]. However, in growthrestricted babies with antenatal doppler abnormalities, due to fear of NEC, there are considerable variations in initiation and advancement of feeds. Feeds are often delayed and are advanced at a slower rate, thereby delaying the enteral nutrition, and placing them at increased risk of parenteral nutrition induced liver failure and infections [6]. Hence, a focused systematic review of the available evidence is needed to reduce the variations and improve outcomes in this vulnerable subset of preterms. In neonates with antenatal abnormal dopplers, we compared the impact of early feeding and rapid advancement of feeds with delayed feeding and slow advancement of feeds, respectively result on neonatal outcomes (Primary/Critical: Necrotizing enterocolitis/NEC and mortality; Secondary/Important: feed intolerance, total parenteral nutrition days, duration of hospitalization, healthcare associated infections, cost of care, and neurodevelopment at 18-24 months of corrected age).

\section{Methods}

The protocol was registered in the PROSPERO database (registration number CRD42020195845) and can be accessed from the website https://www.crd.york.ac.uk/PROSPERO/. We followed the Cochrane handbook for systematic reviews of interventions [7], the PRISMA (preferred reporting items for systematic reviews and meta-analyses) reporting guidelines [8], and the GRADE handbook [9]. The differences between the protocol and final review are provided in the online supplemental material.

We included all randomized controlled studies comparing early versus delayed feeding, and slow versus rapid feed advancement in neonates with antenatal doppler abnormalities. The population of interest was preterm neonates (<37 weeks) with antenatal doppler abnormalities defined as absent or reverse end diastolic flow (AREDF), or increased resistance to blood flow in ductus venosus and inferior vena cava, or middle cerebral artery redistribution. Early feeding was defined as feed initiation within $48-72$ hours of birth, and delayed feeding was defined as feed initiation beyond this time point. Slow advancement was defined as $<20-30 \mathrm{ml} / \mathrm{kg} /$ day advancement per day, and rapid advancement as $>20-30 \mathrm{ml} / \mathrm{kg} / \mathrm{day}$.

The databases of PubMed, Embase, CINAHL, Cochrane CENTRAL, and Google Scholar were searched on the 6th of September 2020 for studies published between 1990 and 5th of September 2020. The search terminology is provided in the online supplemental material. We also searched for grey literature from various sources like dissertation websites and contacting researchers who have worked on this subject.

We included the studies when they provided data on at least one of the pre-specified outcomes. These outcomes included feeding intolerance ( 1 or more of the following: $>50 \%$ prefeed aspirates, abdominal girth increase by $>2 \mathrm{~cm}$, vomiting, bilious aspirates, blood in stools), necrotizing enterocolitis stage 2 or more (modified Bell's staging), time to attain full enteral feeds (at least $150 \mathrm{ml} / \mathrm{kg} / \mathrm{d}$ ), duration of total parenteral nutrition (TPN), mortality, health-care associated infections (culture proven sepsis), duration of hospital stay, cost of care, and neurodevelopmental outcomes at 18-24 months corrected age. We excluded conference abstracts and letters to the editor without original data, and studies published in languages other than English. We excluded studies done in growth-restricted babies without data on antenatal doppler findings.

The database search was performed by 2 reviewers (AS and RP). The studies obtained by database search were entered into Rayyan software. After excluding duplicates and non-English studies, the titles and abstracts were assessed for eligibility by 2 reviewers independently (AS and RP), and any discrepancy was

Page 2/12 
sorted out by mutual discussion, or involvement of the third reviewer (SM). The following data were extracted by RP and AS in a blinded manner: study identification details; study characterisitics including the study setting, study design, feeding strategies, definitions used for feed intolerance, NEC, and hospital-acquired infections; population characteristics including the gestational age, birth weight, gender, antenatal steroid use, mode of delivery, chorioamnionitis, and resuscitation details; feeding strategy in the intervention and control arms (timing of initiation, type of milk used, volume at initiation, rapidity of advancement, and volume of feed advancement); and the data on aforementioned outcomes. When the data were missing/ unclear, we contacted the corresponding author through email. Any discrepancy was resolved by discussion, or by consulting the third reviewer (SM).

We assessed the risk of bias (ROB) of included studies using the Cochrane Risk of Bias tool, version 2 for randomised controlled trials [10]. We assessed the methods used for random sequence generation, allocation concealment, blinding of participants and personnel, blinding of outcome assessment, selective reporting, and completeness of outcome data. An intention to treat analysis was considered desirable. The assessment was done by 2 reviewers (RP and AS) in a blinded manner from all the eligible studies. Any discrepancy was resolved by discussion, or by consulting the third reviewer (SM).

Studies (or outcomes) deemed comparable were pooled to include in the meta-analysis. A random-effect model meta-analysis was performed using the Cochrane statistical package, RevMan 5.4 software, for each outcome if two or more studies were available. The comparative effect sizes were calculated as risk ratios (RR) and risk difference (RD) for categorical outcomes and mean differences (MD) for continuous outcomes with their $95 \%$ confidence intervals (Cls). The pooled estimates were depicted using forest plots. We used Cochrane handbook recommended formulae for converting median to mean; and range, interquartile range and $95 \%$ confidence intervals to standard deviations (online supplemental material). Heterogeneity was assessed using the $\mathrm{I}^{2}$ statistic [11]. We planned subgroup and sensitivity analysis based on the type of doppler abnormalities (AEDF or REDF), intrauterine growth status (small-for-gestational age and appropriate-for gestational age), and gestational age (< 28 weeks, $29-31$ weeks, and $>32$ weeks). We planned to assess heterogeneity by comparing important factors in trial design (bias), intervention (feeding strategy), and co-interventions (probiotics, mothers' own milk use, and antibiotic usage rates). Assessment of publication bias was planned if the number of studies exceeded 10. The Cochrane Grading of Recommendations Assessment, Development and Evaluation (GRADE) approach was used to assess the certainty of evidence [9].

\section{Results}

Our search strategy yielded 2,830 studies (Figure 1- PRISMA flow diagram). After assessing 9 full-text articles, we included 7 studies in the meta-analysis [1218]. While 6 studies assessed early versus delayed feeding, 1 study assessed slow versus rapid feed advancement [18]. The characteristics of included studies are provided in Table 1. The characteristics of the participants are provided in Table 2. The characteristics of excluded studies are provided in the online supplemental material. 
Table 1

Characteristics of included studies

\begin{tabular}{|c|c|c|c|c|c|c|}
\hline Author & Study setting & Inclusion criteria & Exclusion criteria & $\begin{array}{l}\text { NEC } \\
\text { definition }\end{array}$ & $\begin{array}{l}\text { Feeding intolerance } \\
\text { definition }\end{array}$ & $\begin{array}{l}\text { Full feeds } \\
\text { definition }\end{array}$ \\
\hline $\begin{array}{l}\text { Abdelmaaboud, } \\
2012\end{array}$ & $\begin{array}{l}\text { Level } 3 \text { NICU, } \\
\text { Doha, Qatar }\end{array}$ & $\begin{array}{l}\text { Fulfilling all the } 5 \text { criteria: (1) } 24- \\
36+6 \text { weeks, }(2)<10 \text { th centile on } \\
\text { Child Growth Foundation Charts, } \\
\text { (3) Antenatal ultrasound showing } \\
\text { IUGR with AREDF on at least } 50 \% \\
\text { of the Doppler waveforms from the } \\
\text { umbilical artery on at least one } \\
\text { occasion during pregnancy and an } \\
\text { evidence of cerebral redistribution, } \\
\text { defined as occurring when both the } \\
\text { umbilical artery pulsatility index } \\
>95 \text { th centile and the middle } \\
\text { cerebral artery pulsatility index }<5 \text { th } \\
\text { centile for gestational age; (4) } \\
\text { Arterial cord blood pH } \geq 7.0, \text { base } \\
\text { deficit } \geq-12 \text { mmol } / L \text { and (5) } 5- \\
\text { minute Apgar score }>5 \text {. }\end{array}$ & $\begin{array}{l}\text { Major congenital } \\
\text { abnormality } \\
\text { including known } \\
\text { chromosomal } \\
\text { abnormality, twin- } \\
\text { twin transfusion, } \\
\text { intra- uterine } \\
\text { transfusion or } \\
\text { exchange } \\
\text { transfusion, rhesus } \\
\text { iso-immunisation, } \\
\text { significant multi- } \\
\text { organ failure and } \\
\text { inotropic drug } \\
\text { support prior to trial } \\
\text { entry or if they } \\
\text { already received } \\
\text { any minimal enteral } \\
\text { feeding }\end{array}$ & $\begin{array}{l}\text { Modified } \\
\text { Bells' } \\
\text { staging } \\
\text { criteria }\end{array}$ & $\begin{array}{l}\text { Gastric residuals were } \\
\text { checked before each } \\
\text { feed. (1) Non-bilious } \\
\text { residuals: } 25-50 \%+ \\
\text { other worrying signs; } \\
>50 \% \text { gastric residuals } \\
+ \text { AG increase }>2 \mathrm{~cm} \text {. } \\
\text { (2) Bilious aspirates. } \\
\text { (3) Blood in stool, } \\
\text { loose stool, metabolic } \\
\text { acidosis and other } \\
\text { signs of NEC }\end{array}$ & $\begin{array}{l}150-160 \\
\mathrm{ml} / \mathrm{kg} / \mathrm{day} \\
\text { sustained for } \\
72 \text { hours }\end{array}$ \\
\hline Arnon, 2013 & $\begin{array}{l}\text { Level } 3 \text { NICU, } \\
\text { Kafar Saba, } \\
\text { Israel }\end{array}$ & $\begin{array}{l}\text { Clinically \& hemodynamically } \\
\text { stable, birth wt }<10 \text { th centile as per } \\
\text { Israel National registry \& gest }<37 \\
\text { wks \& AREDF }\end{array}$ & $\begin{array}{l}\text { Systemic disease, } \\
\text { need for } \\
\text { mechanical } \\
\text { ventilation, major } \\
\text { congenital } \\
\text { anomalies } \\
\text { including known } \\
\text { chromosomal } \\
\text { abnormality, enteral } \\
\text { feeding before } \\
\text { study entry, use of } \\
\text { anti-reflux } \\
\text { medication or } \\
\text { special diet before } \\
\text { or during the } \\
\\
\text { study period, Apgar } \\
\text { score } 0 \text { to } 3 \text { for }>5 \\
\text { minutes, arterial } \\
\text { cord blood pH }<7.0 \\
\text { or base deficit } 12 \text { to } \\
16 \text { mmol/L, need } \\
\text { for resuscitation, or } \\
\text { significant multi- } \\
\text { organ failure. }\end{array}$ & $\begin{array}{l}\text { No } \\
\text { mention }\end{array}$ & $\begin{array}{l}\text { Clinical signs of } \\
\text { abdominal distension/ } \\
\text { tenderness, visible } \\
\text { bowel loops or emesis, } \\
\text { gastric residuals }>50 \% \\
\text { of } 3 \mathrm{hr} \text { volume }\end{array}$ & $150 \mathrm{ml} / \mathrm{kg}$ \\
\hline $\begin{array}{l}\text { Karagianni, } \\
2009\end{array}$ & $\begin{array}{l}\text { Level } 3 \text { NICU, } \\
\text { Greece }\end{array}$ & $\begin{array}{l}27-34 \text { weeks, Birth wt }<10 \text { th centile, } \\
\text { Abnormal Doppler (elevated } \\
\text { Pl>90th centile), arterial cord } \mathrm{pH}>7 \\
\text { (base deficit }>-12 \mathrm{mmol} / \mathrm{L} \text { ) and } 5 \\
\text { min APGAR }>5\end{array}$ & $\begin{array}{l}\text { Major congenital } \\
\text { anomalies, } \\
\text { infections, signs of } \\
\text { genetic syndromes } \\
\text { and gastrointestinal } \\
\text { tract anomalies, } \\
\text { exchange } \\
\text { transfusion, } \\
\text { inotropic support }\end{array}$ & $\begin{array}{l}\text { Bell's } \\
\text { criteria } 2 \& \\
3\end{array}$ & $\begin{array}{l}\text { Gastric residuals, } \\
\text { bilious vomiting, } \\
\text { abdominal distension }\end{array}$ & $\begin{array}{l}\text { Not } \\
\text { mentioned }\end{array}$ \\
\hline Leaf, 2012 & $\begin{array}{l}\text { Southampton, } \\
\text { Multicentre, } \\
\text { UK }\end{array}$ & $\begin{array}{l}\text { Preterm (up to } 34+6 \text { weeks of } \\
\text { gestation), SGA (birth weight below } \\
\text { 10th centile23), ,48 hours postnatal } \\
\text { age, and had abnormal antenatal } \\
\text { Doppler studies indicative of IUGR. } \\
\text { This was defined as the following: } \\
\text { (1) AREDFV in the umbilical artery } \\
\text { seen on at least } 50 \% \text { of waveforms } \\
\text { on at least } 1 \text { occasion during } \\
\text { pregnancy, or (2) cerebral re-- } \\
\text { distribution (umbilical artery } \\
\text { pulsatility index }>95 \text { th centile and } \\
\text { middle cerebral artery pulsatitility } \\
\text { index < } 5 \text { th centile for gestation) }\end{array}$ & $\begin{array}{l}\text { Major congenital } \\
\text { anomaly, twin- twin } \\
\text { transfusion, Rhesus } \\
\text { iso-immunization, } \\
\text { previous } \\
\text { intrauterine or } \\
\text { exchange trans- } \\
\text { fusion, multiorgan } \\
\text { dysfunction, } \\
\text { inotropic drug } \\
\text { support, or enteral } \\
\text { feeding before trial } \\
\text { entry }\end{array}$ & $\begin{array}{l}\text { modified } \\
\text { Bell's } \\
\text { stage 1, 2, } \\
\text { or } 3\end{array}$ & Not mentioned & $\begin{array}{l}150 \mathrm{ml} / \mathrm{kg} / \mathrm{d} \\
\text { sustained- } \\
72 \mathrm{hrs}\end{array}$ \\
\hline
\end{tabular}

NEC- necrotizing enterocolitis, NICU- neonatal intensive care unit, IUGR- intrauterine growth retardation, AG- abdominal girth, AREDF- absent or reversal of end diastolic flow, UA- umbilical artery. 


\begin{tabular}{|c|c|c|c|c|c|c|}
\hline Author & Study setting & Inclusion criteria & Exclusion criteria & $\begin{array}{l}\text { NEC } \\
\text { definition }\end{array}$ & $\begin{array}{l}\text { Feeding intolerance } \\
\text { definition }\end{array}$ & $\begin{array}{l}\text { Full feeds } \\
\text { definition }\end{array}$ \\
\hline $\begin{array}{l}\text { Srinivasan, } \\
2017\end{array}$ & $\begin{array}{l}\text { Level } 3 \text { NICU, } \\
\text { Mumbai, } \\
\text { India }\end{array}$ & $\begin{array}{l}\text { Preterm (up to } 36+6 \text { weeks of } \\
\text { gestation), } 24 \text { hours postnatal age, } \\
\text { and had abnormal antenatal } \\
\text { Doppler studies indicative of IUGR. } \\
\text { This was defined as the following: } \\
\text { (1) AREDF in the umbilical artery } \\
\text { seen on at least } 50 \% \text { of waveforms } \\
\text { on at least } 1 \text { occasion during } \\
\text { pregnancy, or }(2) \text { cerebral re-- } \\
\text { distribution (umbilical artery } \\
\text { pulsatility index .95th centile and } \\
\text { middle cerebral artery pulsatitility } \\
\text { index }, 5 \text { th centile for gestation) }\end{array}$ & $\begin{array}{l}\text { Major congenital } \\
\text { anomaly, twin- twin } \\
\text { transfusion, Rhesus } \\
\text { iso-immunization, } \\
\text { previous } \\
\text { intrauterine or } \\
\text { exchange trans- } \\
\text { fusion, multiorgan } \\
\text { dysfunction, } \\
\text { inotropic drug } \\
\text { support, or enteral } \\
\text { feeding before trial } \\
\text { entry }\end{array}$ & $\begin{array}{l}\text { Not } \\
\text { mentioned }\end{array}$ & Not mentioned & $\begin{array}{l}\text { Not } \\
\text { mentioned }\end{array}$ \\
\hline Tewari, 2017 & $\begin{array}{l}\text { Level3 NICU, } \\
\text { Delhi, India }\end{array}$ & $\begin{array}{l}<32 \text { weeks with AREDF on UA } \\
\text { Doppler and birth weight below the } \\
10 \text { th centile }\end{array}$ & $\begin{array}{l}\text { Extramural, } \\
\text { symmetric IUGR, } \\
\text { antenatally } \\
\text { suspected intestinal } \\
\text { anomaly, lethal } \\
\text { congenital anomaly, } \\
\text { dysmorphic, needed } \\
\text { invasive ventilation, } \\
\text { inotropic support or } \\
\text { extensive } \\
\text { resuscitation and } \\
\text { parent unavailable. } \\
\text { Intramural preterm } \\
\text { IUGR neonates }<27 \\
\text { weeks }\end{array}$ & $\begin{array}{l}\text { Not } \\
\text { defined }\end{array}$ & $\begin{array}{l}\text { Abdominal girth }>2 \mathrm{~cm} \\
\text { increase over baseline } \\
\text { in } 24 \text { h; Pre-feed } \\
\text { aspirate volume }>50 \% \\
\text { of feed volume; Pre- } \\
\text { feed aspirate color: } \\
\text { Bilious/ altered or } \\
\text { fresh blood; }>1 \\
\text { vomitus with yellow or } \\
\text { green color and/ or } \\
\text { altered blood }\end{array}$ & $\begin{array}{l}150- \\
180 \mathrm{ml} / \mathrm{kg} / \mathrm{d} \\
\text { allowing for } \\
\text { weight gain } \\
\text { consistently } 3 \\
\text { days }\end{array}$ \\
\hline Jain, 2015 & $\begin{array}{l}\text { Level } 3 \text { NICU, } \\
\text { Chandigarh, } \\
\text { India }\end{array}$ & $\begin{array}{l}\text { AEDF who were } \geq 1000 \mathrm{~g} \text { and } \\
\text { between } 30-36 \text { weeks }\end{array}$ & $\begin{array}{l}\text { Perinatal asphyxia } \\
\text { (Apgar score at } 5 \\
\text { minutes }<6 \text { ), REDF, } \\
\text { shock or inotrope } \\
\text { dependency, any } \\
\text { gastrointestinal } \\
\text { tract or other major } \\
\text { congenital } \\
\text { malformation }\end{array}$ & $\begin{array}{l}\text { Bell's } \\
\text { criteria }\end{array}$ & $\begin{array}{l}\text { Any two of these } \\
\text { criteria: gastric } \\
\text { residuals }>33 \% \text { of total } \\
\text { feeds on } 2 \text { consecutive } \\
\text { occasions (if total feed } \\
\text { volume }>8 \mathrm{ml} \text { ) or }>50 \% \\
\text { on a single occasion } \\
\text { (if total feed volume } \\
\text { was }<8 \mathrm{ml} \text { ), abdominal } \\
\text { distension (increase in } \\
\text { abdominal girth by } \\
>2 \mathrm{~cm} \text { from baseline), } \\
\text { brown, bilious, or blood } \\
\text { stained gastric } \\
\text { aspirates, vomiting for } \\
\text { which feeds were } \\
\text { withheld for } \geq 12 \text { hours } \\
\text { and absent bowel } \\
\text { sounds on } \\
\text { auscultation in two } \\
\text { different quadrants for } \\
\text { two minutes confirmed } \\
\text { by second observer. }\end{array}$ & $150 \mathrm{ml} / \mathrm{kg} /$ day \\
\hline
\end{tabular}

Table 2: Characteristics of neonates participating in the included studies 


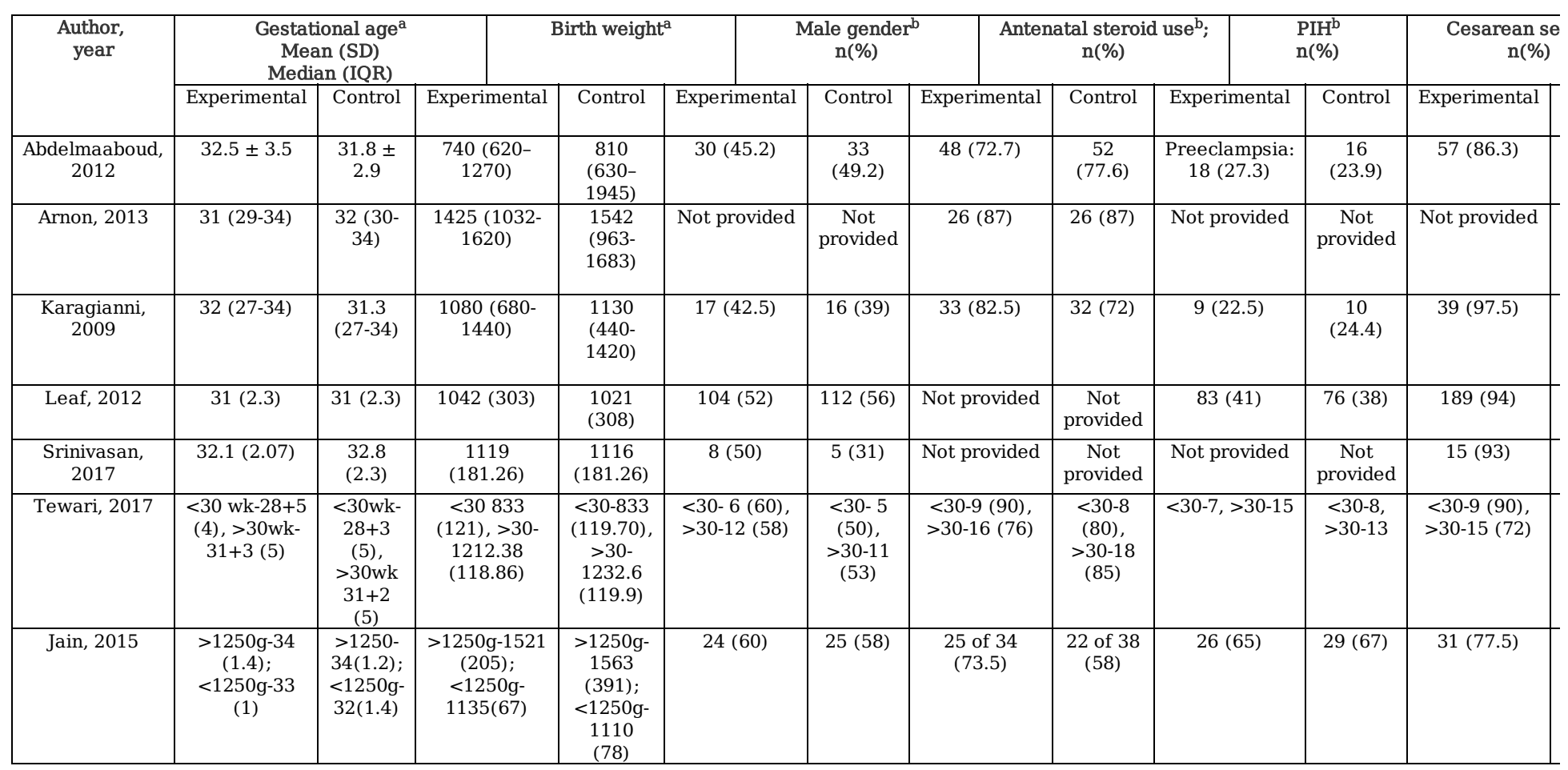

a- mean (SD); b- n (\%); c- median (IQR)

SD- standard deviation, IQR- interquartile range, PIH- Pregnancy Induced Hypertension.

In three studies, the neonates were <37 weeks gestational age [12,13,16], while 3 other studies included neonates up to 32 weeks [17], 34 weeks [14], and 35 weeks [15]. In five studies, all the neonates included were small for gestational age, while in one study [16], it was not reported. In the five studies that provided data on antenatal steroid use [12-14, 17, 18], no significant differences were noted between the experimental and control arms. None of the studies provided data on the duration of doppler abnormalities, chorioamnionitis and sickness scores at admission to NICU. Jain et al have restricted study population to neonates between $30-36$ weeks and weight above 1,000 grams; $60 \%$ of neonates in the experimental arm and $63 \%$ in the control arm were growth-restricted [18].

While donor human milk was provided as a second option when breast milk was unavailable in the three recent studies [15-17], infant formula was provided in the other four studies [12-14, 18]. The human milk was fortified at feed volumes of $100-150 \mathrm{ml} / \mathrm{kg}$ in three studies [12, 13, 15], while it was unclear in the others. None of the studies have reported the use of probiotics. The definitions used for NEC (modified Bell's staging) and full feeds (150-180 ml/kg/day sustained for 3 days) were consistent across the studies. Feeding intolerance was variably defined in five studies [12-14, 17, 18], while it was not defined in the other two studies $[15,16]$. In all the studies, $>50 \%$ pre-feed volumes, blood in stool, bilious aspirates and abdominal signs were considered worrisome.

In five studies, early feeding was defined as feeding within 48 hours of birth, while in one study, it was defined as $<5$ days of birth [14]. The volume at feed initiation varied from $4-30 \mathrm{ml} / \mathrm{kg} /$ day, duration of trophic feeds from $0-6$ days, and volume of feed advancement from $12-35 \mathrm{ml} / \mathrm{kg} / \mathrm{day}$. In $2 \mathrm{studies}$, the feed initiation and advancement were stratified according to the birth weight $[15,17]$. In the study by Jain et al, rapid advancement was defined as 30 $\mathrm{ml} / \mathrm{kg} /$ day in neonates weighing $1-1.25 \mathrm{~kg}$, and $40 \mathrm{ml} / \mathrm{kg} /$ day in those weighing $>1.25 \mathrm{~kg}$ [18]. Slow advancement was defined as $20 \mathrm{ml} / \mathrm{kg} / \mathrm{day}$ and 30 $\mathrm{ml} / \mathrm{kg} /$ day in the above weight ranges, respectively. Further details of feed initiation and advancement in the experimental and control arms are summarized in the online supplemental material.

When compared to delayed feeding, the strategy of early feeding did not increase the incidence of NEC stage 2 or more (odds ratio/OR 1.27 , $95 \%$ confidence interval/Cl $0.83,1.96)$ and mortality (OR $0.79,95 \% \mathrm{Cl} 0.4,1.57)$. A trend was noted towards an increased incidence of feeding intolerance $(\mathrm{OR} 1.37,95 \% \mathrm{Cl}$ $0.98,1.92$ ). There was a significant reduction in time to reach full feeds (mean difference/MD -3.03 days. $95 \% \mathrm{Cl}-3.53,-2.53$ days), duration of total parental nutrition (MD -3.14 days, $95 \% \mathrm{Cl}-3.98,-2.3$ days), and duration of hospital stay (MD -4.98 days, $95 \% \mathrm{Cl}-8.31,-1.65$ days). There was also a significant reduction in rates of hospital-acquired infections (OR $0.67,95 \% \mathrm{Cl} 0.45,0.98)$. The time to regain birth weight was not different. The forest plots are shown in figure 2 .

On the risk of bias assessment using RoB2 tool, 5 studies were adjudged to have some concerns [12-14, 16, 17], while 1 study had a low risk of bias [15]. For outcomes with subjectivity in assessment (i.e., feeding intolerance), 4 studies were adjudged to be at high risk of bias due to lack of blinding of outcome assessment [12, 15-17]. The assessment is shown in Table 3 and the criteria used in the online supplemental material. Heterogeneity was not noted for the outcomes studied, except the duration of hospital stay $\left(I^{2}=35 \%\right)$. Subgroup analysis, sensitivity analysis and publication bias assessment were not performed because of the small number of eligible studies. 
Table 3

Risk of bias in the included studies

\begin{tabular}{|c|c|c|c|c|c|c|c|}
\hline Author, year & $\begin{array}{l}\text { Randomization } \\
\text { process }\end{array}$ & $\begin{array}{l}\text { Deviations from } \\
\text { intended interventions }\end{array}$ & $\begin{array}{l}\text { Missing } \\
\text { outcome } \\
\text { data }\end{array}$ & $\begin{array}{l}\text { Measurement of } \\
\text { the outcome }\end{array}$ & $\begin{array}{l}\text { Selection of the } \\
\text { reported result }\end{array}$ & $\begin{array}{l}\text { Overall } \\
\text { Bias }\end{array}$ & Overall effect \\
\hline $\begin{array}{l}\text { Abdelmaaboud, } \\
2012\end{array}$ & $\begin{array}{l}\text { Some } \\
\text { concerns }^{a}\end{array}$ & Low & Low & Low $^{d}$ & Some concerns ${ }^{\mathrm{e}}$ & $\begin{array}{l}\text { Some } \\
\text { concerns }^{g}\end{array}$ & $\begin{array}{l}\text { Favours } \\
\text { experimental }\end{array}$ \\
\hline Arnon, 2013 & $\begin{array}{l}\text { Some } \\
\text { concerns }^{b}\end{array}$ & Low & Low & Low & Some concerns ${ }^{f}$ & $\begin{array}{l}\text { Some } \\
\text { concerns }\end{array}$ & $\begin{array}{l}\text { Favours } \\
\text { experimental }\end{array}$ \\
\hline $\begin{array}{l}\text { Karagianni, } \\
2009\end{array}$ & $\begin{array}{l}\text { Some } \\
\text { concerns }^{a}\end{array}$ & Some concerns ${ }^{c}$ & Low & Low & Some concerns ${ }^{\mathrm{e}}$ & $\begin{array}{l}\text { Some } \\
\text { concerns }\end{array}$ & $\begin{array}{l}\text { Favours } \\
\text { experimental }\end{array}$ \\
\hline Leaf, 2012 & Low & Low & Low & Low $^{d}$ & Low & Low $^{g}$ & Unpredictable \\
\hline $\begin{array}{l}\text { Srinivasan, } \\
2017\end{array}$ & Low & Low & Low & Low $^{d}$ & Some concerns ${ }^{\mathrm{e}}$ & $\begin{array}{l}\text { Some } \\
\text { concerns }^{g}\end{array}$ & Unpredictable \\
\hline Tewari, 2017 & Low & Low & Low & Low $^{d}$ & Some concerns ${ }^{\mathrm{e}}$ & $\begin{array}{l}\text { Some } \\
\text { concerns }^{g}\end{array}$ & Unpredictable \\
\hline Jain, 2015 & Low & Low & Low & Low & Low & Low & NA \\
\hline \multicolumn{8}{|c|}{ a- Methods to generate random sequence and conceal allocation not mentioned. } \\
\hline \multicolumn{8}{|c|}{ b- No information provided on allocation concealment } \\
\hline \multicolumn{8}{|c|}{ c- Post randomization exclusions were done } \\
\hline \multicolumn{8}{|c|}{$\begin{array}{l}\text { d- Outcome assessors were not blinded for the intervention. The prior knowledge can influence assessment of outcomes of feed intolerance. Hence, the } \\
\text { assessment for this outcome is high risk of bias. For other outcomes like necrotizing enterocolitis stage } 2 \text { or more, mortality, duration of parenteral } \\
\text { nutrition, duration of hospital stay, hospital acquired sepsis, time to reach full feeds and time to regain birth weight, prior knowledge is unlikely to influence } \\
\text { assessment of outcomes. They were adjudged to be at low risk of bias. }\end{array}$} \\
\hline \multicolumn{8}{|c|}{ e- Trail protocol, registration details, and statistical analysis plan not available } \\
\hline \multicolumn{8}{|c|}{$\begin{array}{l}\text { f- The published protocol mentions this as an observational study for electrogastrography (EGG). Hence, in effect, this protocol was not published/ or is } \\
\text { planned as the study progressed }\end{array}$} \\
\hline
\end{tabular}

On GRADE assessment, the certainty of evidence was rated high for days on parenteral nutrition; moderate for mortality, and time to reach full feeds; low for NEC 2 or more, hospital-acquired sepsis, duration of hospital stay, and time to regain birth weight; and very low for feeding intolerance (Table 4).

Table 4. GRADE evidence profile

Comparison 1: Early versus delayed initiation of feed in neonates with antenatal doppler abnormalities 


\begin{tabular}{|c|c|c|c|c|c|c|c|c|c|c|c|c|}
\hline \multicolumn{7}{|c|}{ Certainty assessment } & \multicolumn{3}{|c|}{ № of patients } & Effect & \multirow[t]{2}{*}{ Certainty } & \multirow[t]{2}{*}{ Importance } \\
\hline $\begin{array}{l}\text { № of } \\
\text { studies }\end{array}$ & $\begin{array}{l}\text { Study } \\
\text { design }\end{array}$ & $\begin{array}{l}\text { Risk of } \\
\text { bias }\end{array}$ & Inconsistency & Indirectness & Imprecision & $\begin{array}{c}\text { Other } \\
\text { considerations }\end{array}$ & Early & $\begin{array}{l}\text { delayed } \\
\text { feed } \\
\text { initiation }\end{array}$ & $\begin{array}{c}\text { Relative } \\
\text { (95\% } \\
\text { CI) }\end{array}$ & $\begin{array}{c}\text { Absolute } \\
\text { (95\% } \\
\text { CI) }\end{array}$ & & \\
\hline \multicolumn{13}{|c|}{ Necrotizing enterocolitis $2 \mathrm{~A}$ or more } \\
\hline 6 & $\begin{array}{c}\text { randomised } \\
\text { trials }\end{array}$ & serious $^{\mathrm{a}}$ & not serious & not serious & serious $^{b}$ & none & $\begin{array}{r}54 / 385 \\
(14.0 \%)\end{array}$ & $\begin{array}{c}44 / 387 \\
(11.4 \%)\end{array}$ & $\begin{array}{c}\text { OR 1.27 } \\
(0.83 \\
\text { to } 1.96)\end{array}$ & $\begin{array}{c}26 \text { more } \\
\text { per } \\
1,000 \\
\text { (from } \\
17 \\
\text { fewer to } \\
87 \\
\text { more) }\end{array}$ & $\underset{\text { Low }}{\oplus \oplus \bigcirc}$ & CRITICAL \\
\hline \multicolumn{13}{|c|}{ Feeding intolerance } \\
\hline 5 & $\begin{array}{c}\text { randomised } \\
\text { trials }\end{array}$ & $\begin{array}{l}\text { very } \\
\text { serious }^{\mathrm{c}}\end{array}$ & not serious & not serious & serious $^{\mathrm{b}}$ & none & $\begin{array}{l}112 / 355 \\
(31.5 \%)\end{array}$ & $\begin{array}{c}90 / 356 \\
(25.3 \%)\end{array}$ & $\begin{array}{c}\text { OR } 1.37 \\
(0.98 \\
\text { to } 1.92)\end{array}$ & $\begin{array}{c}64 \text { more } \\
\text { per } \\
1,000 \\
\text { (from } 4 \\
\text { fewer to } \\
141 \\
\text { more) } \\
\end{array}$ & $\begin{array}{l}\oplus \bigcirc 0 \bigcirc \\
\text { Very low }\end{array}$ & IMPORTANT \\
\hline \multicolumn{13}{|c|}{ Time to reach full feeds } \\
\hline 5 & $\begin{array}{c}\text { randomised } \\
\text { trials }\end{array}$ & serious $^{\mathrm{d}}$ & not serious & not serious & not serious & none & 345 & 346 & - & $\begin{array}{c}\text { MD } 3.03 \\
\text { lower } \\
(3.53 \\
\text { lower to } \\
2.53 \\
\text { lower) } \\
\end{array}$ & $\begin{array}{l}\oplus \oplus \oplus \bigcirc \\
\text { Moderate }\end{array}$ & IMPORTANT \\
\hline \multicolumn{13}{|c|}{ Duration of hospital stay } \\
\hline 5 & $\begin{array}{c}\text { randomised } \\
\text { trials }\end{array}$ & serious $^{\mathrm{d}}$ & not serious & not serious & serious $^{b}$ & none & 345 & 945 & - & $\begin{array}{c}\text { MD } 4.98 \\
\text { lower } \\
\text { (8.31 } \\
\text { lower to } \\
1.65 \\
\text { lower) } \\
\end{array}$ & $\underset{\text { Low }}{\oplus \oplus 0}$ & IMPORTANT \\
\hline \multicolumn{13}{|c|}{ Mortality } \\
\hline 3 & $\begin{array}{l}\text { randomised } \\
\text { trials }\end{array}$ & $\begin{array}{c}\text { not } \\
\text { serious }\end{array}$ & not serious & not serious & serious $^{b}$ & none & $\begin{array}{l}16 / 249 \\
(6.4 \%)\end{array}$ & $\begin{array}{l}20 / 249 \\
(8.0 \%)\end{array}$ & $\begin{array}{c}\text { OR } 0.79 \\
(0.40 \\
\text { to } 1.57)\end{array}$ & $\begin{array}{c}16 \\
\text { fewer } \\
\text { per } \\
1,000 \\
\text { (from } \\
47 \\
\text { fewer to } \\
40 \\
\text { more) }\end{array}$ & $\begin{array}{l}\oplus \oplus \oplus \bigcirc \\
\text { Moderate }\end{array}$ & CRITICAL \\
\hline \multicolumn{13}{|c|}{ Hospital acquired sepsis } \\
\hline 4 & $\begin{array}{c}\text { randomised } \\
\text { trials }\end{array}$ & serious $^{\mathrm{e}}$ & not serious & not serious & serious $^{b}$ & none & $\begin{array}{c}63 / 279 \\
(22.6 \%)\end{array}$ & $\begin{array}{r}85 / 279 \\
(30.5 \%)\end{array}$ & $\begin{array}{l}\text { OR } 0.67 \\
(0.45 \\
\text { to } 0.98)\end{array}$ & $\begin{array}{c}78 \\
\text { fewer } \\
\text { per } \\
1,000 \\
\text { (from } \\
140 \\
\text { fewer to } \\
4 \text { fewer) }\end{array}$ & $\underset{\text { Low }}{\oplus \oplus \bigcirc}$ & IMPORTANT \\
\hline \multicolumn{13}{|c|}{ Days on total parenteral nutrition } \\
\hline 3 & $\begin{array}{l}\text { randomised } \\
\text { trials }\end{array}$ & $\begin{array}{c}\text { not } \\
\text { serious }\end{array}$ & not serious & not serious & not serious & none & 249 & 249 & - & $\begin{array}{c}\text { MD } 3.14 \\
\text { lower } \\
(3.98 \\
\text { lower to } \\
2.3 \\
\text { lower) }\end{array}$ & $\underset{\text { High }}{\oplus \oplus \oplus}$ & IMPORTANT \\
\hline \multicolumn{13}{|c|}{ Time to regain birth weight } \\
\hline 2 & $\begin{array}{c}\text { randomised } \\
\text { trials }\end{array}$ & serious $^{f}$ & not serious & not serious & serious $^{b}$ & none & 97 & 98 & - & $\begin{array}{c}\text { MD 4.15 } \\
\text { higher } \\
(9.57 \\
\text { lower to } \\
17.86 \\
\text { higher })\end{array}$ & $\underset{\text { Low }}{\oplus \oplus 0}$ & IMPORTANT \\
\hline
\end{tabular}

CI: confidence interval; MD: mean difference; OR: odds ratio

\section{Explanations}

a. Of the 6 studies, 3 had "some concerns" in the randomization process, 1 due to deviation from intended intervention, and 5 studies in the selection of reported results.

b. The confidence intervals are wide

c. Of the 5 studies, 4 were adjudged to be at high risk of bias in the measurement of the outcome due to lack of blinding of outcome assessors. 2 studies had some concerns in the randomization process, 1 due to deviation from the intended intervention, and 4 in the selection of the reported result.

d. Of the 5 studies, 2 had some concerns in the randomization process and 4 in the selection of the reported result.

e. Of the 4 studies, 1 study had some concerns in the randomization process, and 3 studies in the selection of the reported outcome.

f. Of the 2 studies, 1 had some concerns in the randomization process and both in the selection of the reported outcome.

Comparison 2: Slow compared to Rapid advancement of feeds for neonates with antenatal doppler abnormalities 


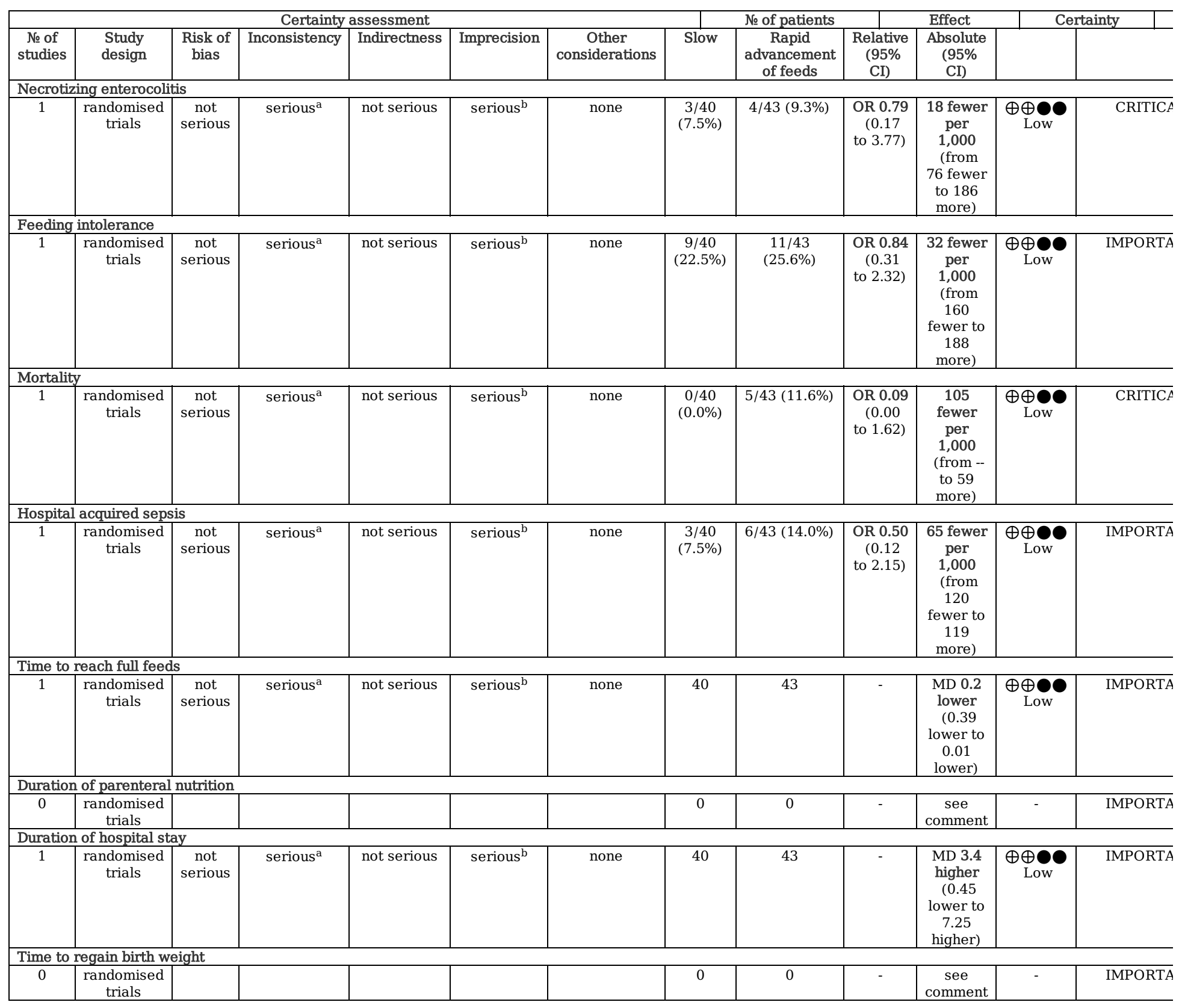

CI: confidence interval; MD: mean difference; OR: odds ratio

Explanations

a. Wide confidence interval

b. Small sample size

When compared to slower feed advancement, rapid feed advancement resulted in decreased time to reach full feeds (MD -0.2 days, $95 \% \mathrm{Cl}-0.39,-0.01)$. There was no difference in other outcomes. The overall risk of bias was adjudged to be low. However, because of the small sample size and wide confidence intervals, the certainty of evidence was rated low.

\section{Discussion}

\section{Summary of main results:}

We evaluated the benefits and harms of early initiation of feeds in neonates with antenatal doppler abnormalities. Six studies with 772 newborns met the inclusion criteria. Early feeding strategy decreased the time to reach full feeds, duration of parenteral nutrition, duration of hospital stay, and rates of hospitalacquired infection. Although there was a trend towards an increase in rates of feeding intolerance, the incidence of NEC did not increase. There was no effect on mortality and time to regain birth weight.

One study with 83 newborns was eligible for assessment of slow versus rapid advancement of feeds. There was a clinically insignificant reduction in time to reach full feeds. Other outcomes were not affected. 
We could not find any review which addressed the same question, and hence are unable to make any comparisons with existing literature.

\section{Overall completeness and applicability of evidence:}

The available evidence is sufficient to understand that early feeding in neonates with antenatal doppler abnormalities does not increase rates of NEC or mortality. However, as only one study assessed the rapidity of feed advancement, with a small sample size, more evidence is needed to answer this question.

\section{Quality of evidence:}

The overall quality of evidence was low. The main factors limiting the quality of evidence were the risk of bias and imprecision in estimates. The risk of bias was predominantly due to problems with the randomization process and selective reporting of the outcomes. The assessment of outcome was not blinded in 4 of the 7 studies, but this is unlikely to impact outcomes other than feeding intolerance.

The only eligible study comparing slow versus rapid feed advancement excluded neonates with extremely low birth weight and gestational age $<30$ weeks, limiting the generalizability. Also, the sample size was very small.

\section{Potential biases in the review process:}

We are unlikely to miss any published literature with the extensive literature search performed. The process of data screening, data extraction and risk of bias assessment was performed by 2 reviewers in a blinded manner and the discrepancies were resolved on group meetings involving the third reviewer. This would minimize the introduction of additional bias. For two studies, we requested data from the author and received the required information [17, 18].

\section{Conclusions}

\section{Implications for practice:}

There is low-quality evidence that early feeding does not increase rates of necrotizing enterocolitis and moderate-quality evidence that it does not impact mortality. There is very low-quality evidence on a trend towards an increased incidence of feeding intolerance. There is low- to moderate-quality evidence on shorter time to reach full feeds, duration of parenteral nutrition, duration of hospital stay, and lower hospital-acquired infections. As benefits outweigh the harms, it is recommended to use the early feeding strategy in neonates with antenatal doppler abnormalities.

There is low quality evidence that rapid feed advancement reduces time to reach full feeds in neonates with gestational age $>30$ weeks, and birth weight $>1 \mathrm{~kg}$. The available data is insufficient to recommend one strategy over the other.

\section{Implication for research:}

Future trials could be undertaken to assess the benefits and harms of early feeding strategies while other evidence-based practices to reduce necrotizing enterocolitis were followed, namely use of probiotics, mothers' own milk and rational antibiotic use. Further studies are necessary in neonates with antenatal doppler abnormalities, but no intrauterine growth retardation. More studies are needed comparing slow versus rapid advancement of feeds.

\section{Declarations}

\section{Acknowledgements: None}

\section{References}

1. Malcolm G, Ellwood D, Devonald K et al (1991) Absent or reversed end diastolic flow velocity in the umbilical artery and necrotising enterocolitis. Arch Dis Child 66:805-807. https://doi.org/10.1136/adc.66.7_spec_no.805

2. Baserga M, Bertolotto C, Maclennan NK et al (2004) Uteroplacental insufficiency decreases small intestine growth and alters apoptotic homeostasis in term intrauterine growth retarded rats. Early Hum Dev 79:93-105. https://doi.org/10.1016/j.earlhumdev.2004.04.015

3. Kosloske AM (1997) The epidemiology and pathogenesis of necrotizing enterocolitis. Semin Neonatol SN 2:231-238. https://doi.org/10.1016/S10842756(97)80029-2

4. Dorling J, Kempley S, Leaf A (2005) Feeding growth restricted preterm infants with abnormal antenatal Doppler results. Arch Dis Child Fetal Neonatal Ed 90:F359-363. https://doi.org/10.1136/adc.2004.060350

5. Patel AL, Panagos PG, Silvestri JM (2017) Reducing Incidence of Necrotizing Enterocolitis. Clin Perinatol 44:683-700. https://doi.org/10.1016/j.clp.2017.05.004

6. Leaf A, Dorling J, Kempley S et al (2009) ADEPT - Abnormal Doppler Enteral Prescription Trial. BMC Pediatr 9:63. https://doi.org/10.1186/1471-2431-9-63

7. Higgins JPT, Cochrane C (2020) Cochrane handbook for systematic reviews of interventions, Second edition. Wiley-Blackwell, Hoboken, NJ

8. Page MJ, McKenzie JE, Bossuyt PM et al (2021) The PRISMA 2020 statement: an updated guideline for reporting systematic reviews. Syst Rev 10:89. https://doi.org/10.1186/s13643-021-01626-4

9. Schünemann H, Brożek J, Guyatt G, Oxman A (2013) GRADE handbook for grading quality of evidence and strength of recommendations. Updated October 2013 
10. Sterne JAC, Savović J, Page MJ et al (2019) RoB 2: a revised tool for assessing risk of bias in randomised trials. BMJ 366:I4898.

https://doi.org/10.1136/bmj.14898

11. Higgins JPT, Thompson SG, Deeks JJ, Altman DG (2003) Measuring inconsistency in meta-analyses. BMJ 327:557-560.

https://doi.org/10.1136/bmj.327.7414.557

12. Abdelmaaboud M, Mohammed A (2012) Early Versus Late Minimal Enteral Feeding in Weeks Preterm Growth-Restricted neonates with Abnormal Antenatal Doppler Studies. J Matern-Fetal Neonatal Med Off J Eur Assoc Perinat Med Fed Asia Ocean Perinat Soc Int.

https://doi.org/10.3109/14767058.2012.695821. Soc Perinat Obstet

13. Arnon S, Sulam D, Konikoff F et al (2013) Very early feeding in stable small for gestational age preterm infants: a randomized clinical trial. J Pediatr (Rio J) 89:388-393. https://doi.org/10.1016/j.jped.2012.12.004

14. Karagianni P, Briana DD, Mitsiakos G et al (2010) Early versus delayed minimal enteral feeding and risk for necrotizing enterocolitis in preterm growthrestricted infants with abnormal antenatal Doppler results. Am J Perinatol 27:367-373. https://doi.org/10.1055/s-0029-1243310

15. Leaf A, Dorling J, Kempley S et al (2012) Early or delayed enteral feeding for preterm growth-restricted infants: a randomized trial. Pediatrics 129:e12601268. https://doi.org/10.1542/peds.2011-2379

16. Srinivasan A, Nanavathi RN, Kabra NS (2017) Comparison of Feeding Regimens in Preterm Neonates with Abnormal Antenatal Doppler: A Randomized Controlled Trial. Glob J Res Anal 6:44-47

17. Tewari VV, Dubey SK, Kumar R et al (2018) Early versus Late Enteral Feeding in Preterm Intrauterine Growth Restricted Neonates with Antenatal Doppler Abnormalities: An Open-Label Randomized Trial. J Trop Pediatr 64:4-14. https://doi.org/10.1093/tropej/fmx018

18. Jain S, Mukhopadhyay K, Jain V, Kumar P (2016) Slow versus rapid enteral feed in preterm neonates with antenatal absent end diastolic flow. J MaternFetal Neonatal Med Off J Eur Assoc Perinat Med Fed Asia Ocean Perinat Soc Int Soc Perinat Obstet 29:2828-2833.

https://doi.org/10.3109/14767058.2015.1105954

\section{Figures}

\section{Figure 1: PRISMA flow diagram}

Identification of studies via databases and registers

Records identified from: Databases $(n=2,798)$

Pubmed $(n=783)$

Embase $(n=647)$

Scopus $(n=893)$

CINAHL $(n=348)$

Cochrane central $(n=46)$

Google scholar $(n=81)$

Records screened

$(n=1,619)$

Reports sought for retrieva

$(n=7)$

Reports assessed for eligibility

$(n=7)$
Records removed before

screening:

Duplicate records removed (

$=1119$ )

Records marked as ineligible

by automation tools $(n=0)$

Records removed for other

reasons- Non-English

literature $(n=60)$

Records excluded

$(n=1,612)$

Reports not retriev ed

$(n=0)$

Reports excluded $(n=1)$

Duplication of another included

study)
Id entification of studies via other methods

Records identified from:

Websites $(n=32)$

Organisations $(n=0)$

Citation searching $(n=0)$

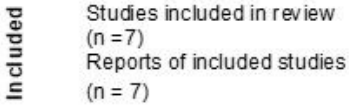

Figure 1

PRISMA flow diagram 

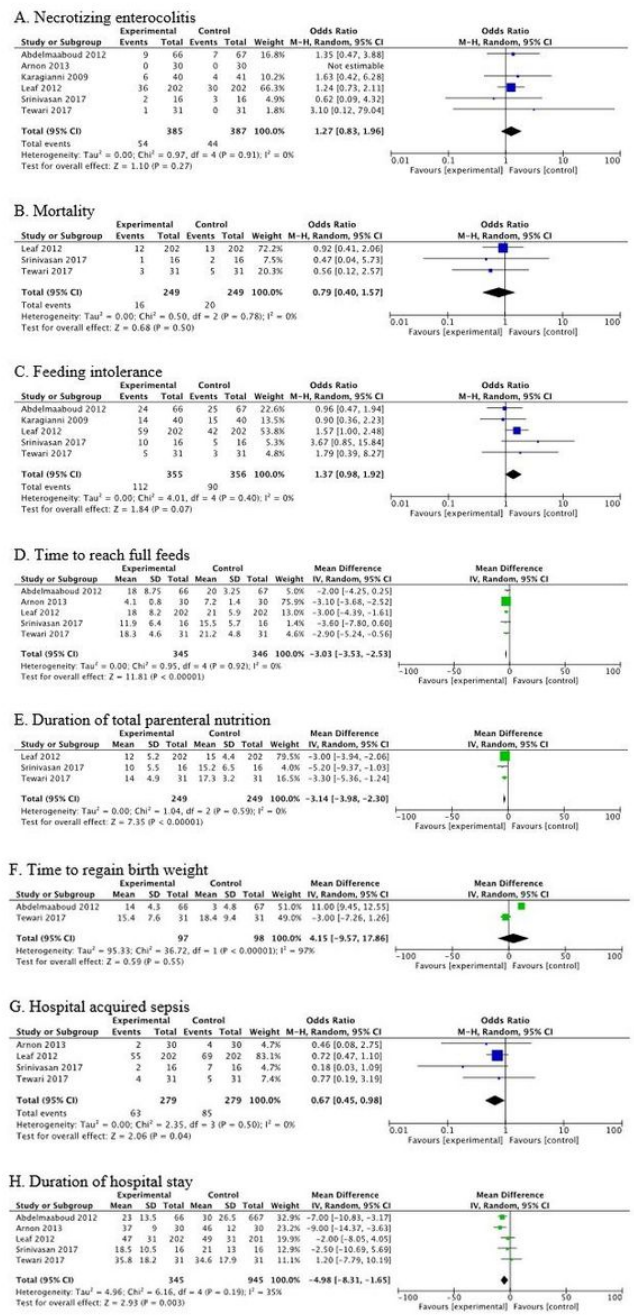

\section{Figure 2}

Forest plots showing comparison of early versus delayed initiation of feeds in neonates with antenatal doppler abnormalities

\section{Supplementary Files}

This is a list of supplementary files associated with this preprint. Click to download.

- Onlinesupplementarymaterial.docx 